Copyright (C) 2020 University of Bucharest Printed in Romania. All rights reserved

ISSN print: $1224-5984$

ISSN online: $2248-3942$
Rom Biotechnol Lett. 2020; 25(2): 1348-1355

doi: $10.25083 / \mathrm{rbl} / 25.2 / 1348.1355$

Received for publication, October, 10, 2016

Accepted, August, 21, 2017

Original paper

\title{
A productive direct regeneration protocol for a wide range of winter squash (Cucurbita maxima Duch.) and pumpkin (Cucurbita moschata Duch.) lines
}

\author{
ERTAN SAIT KURTAR ${ }^{1 *}$, AHMET BALKAYA ${ }^{2}$, DILEK KANDEMIR ${ }^{3}$ \\ ${ }^{1}$ Horticulture Department of Agriculture Faculty, Selcuk University, Konya, Turkey \\ ${ }^{2}$ Horticulture Department of Agriculture Faculty, Ondokuz Mayıs Univ. Samsun, Turkey \\ ${ }^{3}$ Vocational High School of Samsun, Ondokuz Mayıs University, Samsun, Turkey
}

\begin{abstract}
The success of Cucurbit transgenic technology depends on regeneration protocol and recovery of transformed plants. Therefore, an efficient regeneration protocol was established for in vitro shoot regeneration from cotyledon explants to optimize the regeneration of multiple adventitious shoots formation in winter squash and pumpkin lines. Proximal parts of cotyledon explants were excised from in vitro seedlings and were cultured on solid MS medium supplemented with various concentrations and combinations of BAP and TDZ. The number of shoot per regenerated explants was ranged from 2.1 (in line 14BO01) to 7.8 (in line 57Sİ21) in MS medium by addition of $0.5 \mathrm{mg} / \mathrm{l} \mathrm{BAP}$ and $1 \mathrm{mg} / \mathrm{l} \mathrm{BAP}+1 \mathrm{mg} / \mathrm{l} \mathrm{TDZ}$, sequentially. The cultures were incubated at $25 \pm 1^{\circ} \mathrm{C}$ and 16 -h photoperiod for 4 to 5 weeks. Donors were effective on shoot formation, and 57SI21 in winter squashes and G9 in pumpkins were superior lines. Regenerated shoots were rooted and elongated on MS medium combined with $0.01 \mathrm{mg} / \mathrm{l}$ IAA. Elongated and rooted plants were acclimatized with $84 \%$ survival rate. Overall, 122 plants (91 of winter squash and 31 of pumpkin) were obtained during the regeneration process. The ploidy analyses revealed that 118 plants were diploid and 4 plants were tetraploid.
\end{abstract}

Keywords Regeneration, cotyledon explants, winter squash, pumpkin.

To cite this article: KURTAR ES, BALKAYA A, KANDEMIR D. A productive direct regeneration protocol for a wide range of winter squash (Cucurbita maxima Duch.) and pumpkin (Cucurbita moschata Duch.) lines. Rom Biotechnol Lett. 2020; 25(2): 1348-1355. DOI: $10.25083 / \mathrm{rbl} / 25.2 / 1348.1355$

*Corresponding author: ERTAN SAİT KURTAR, Horticulture Department of Agriculture Faculty, Selcuk University, Konya, Turkey

E-mail: ertansaitkurtar@selcuk.edu.tr 


\section{Introduction}

In Turkey, winter squash and pumpkin are widely cultivated for their seeds and mature fruits. C. maxima $\mathrm{x}$ C. moschata hybrids are also used as a rootstock for watermelon and cucumber. However, some viral pathogens (particularly ZYMW) restrict the cultivation and cause a substantial reduction in yield and quality. Actually, all commercial winter squash and pumpkins are local populations (exception Arican 97) and virus-resistant hybrid cultivars have not yet been developed in Turkey.

Although winter squash and pumpkin have significant economic importance, very little work has been carried out on breeding efforts for these species. On the other hand, development of new multi-resistant winter squash and pumpkin lines by classic breeding methods is still limited due to the narrow genetic base, time-consuming procedures, and cross-incompatibility.

Plant biotechnology appears to be an alternative method to overcome these handicaps and this technique has unique advantages for developing new winter squash and pumpkin cultivars with desirable agronomic and economic traits such as resistance to biotic and abiotic stress conditions, high yield and fruit quality. Genetic engineering could be easily applied in winter squash and pumpkin, because of the small-sized genome, high polymorphism and short generation time (ZHANG et al [1]). However, the success of genetic transformation highly depends on the determination of rapid and efficient in vitro plant regeneration protocols. Thus, optimization of clonal propagation method is a key point for the success of regeneration of transgenic plants.

There are only two in vitro regeneration protocols have been reported for C. maxima) (LEE et al [2]) and C. moschata (ZHANG et al [3]). Otherwise, efficient plant regeneration protocols have been developed and generated in Cucumis sativus (VASEDUVAN et al [4]; GROZEVA and VELKOV [5]), Citrullus lanatus (WANG et al [6]; ZHANG et al [7]), Cucumis melo (CURUK et al [8]; RHIMI et al [9]; TEKDAL and CETINER [10]) and Cucurbita pepo (LEE et al [2]; ANANTHAKRISHNAN et al [11]; STIPP et al [12]; MOOKHAN [13]).

It has been well known that genotype, explants type, and composition of the medium are important factors on organogenesis. Furthermore, the physiological conditions and hormonal contents of explants are crucial points for regeneration potential (ZHANG et al [3]; MENDI et al [14]; PETROVA et al [15]). Proximal cotyledon part with hypocotyl segment collected from in vitro germinated seedling was found as the best explant type for the regeneration in winter squash (LEE et al [2]) and pumpkin (ZHANG et al [3]). Although clonal plants were successfully propagated in aforementioned research, only 2 winter squashes and 1 pumpkin genotype were used for in vitro regeneration. However, winter squashes and pumpkins have a wide range of genetic variation, and a regeneration survey should be established in a broad sense for representing of differences of these genotypes during in vitro regeneration process.

The purpose of the present study was to determine a reproducible in vitro regeneration pathway to dominate the genetic engineering for the production of local F1 winter squash and pumpkin cultivars with desirable multiple traits. Hence, this present study was conducted to determine the effects of different concentrations of BAP and TDZ alone or in combinations on in vitro propagation. In this study, a reproducible regeneration protocol was established for 4 winter squash and 2 pumpkin lines from cotyledon explants. To the author's knowledge, this is the first report of treatment with combinations of BAP and TDZ for in vitro shoot regeneration in these species.

\section{Materials and Methods}

\section{Seed Material, Explant Preparation and Culture Conditions}

The experiment was carried out using mature and oneyear-old seeds of four winter squashes (57Sİ21, 55BA03, 55ÇA06 and 55ÇA15) and two pumpkins (14BO01 and G9) lines. The seeds were rinsed for $15 \mathrm{~min}$ and the seed coats peeled gently. Seeds were then immersed in $70 \%$ (v/ v) ethanol for $2 \mathrm{~min}$, followed by a $10 \mathrm{~min}$ in a $10 \%$ (v / v) commercial bleach solution containing two drops Tween-20 per $100 \mathrm{ml}$ solution with shaking. Subsequently, seeds were rinsed five times with sterile distilled water for 5 min each time and were placed on sterilized filter paper to desiccate excessive surface water. Afterward, the seeds were placed vertically on solid MS medium supplemented with $30 \mathrm{~g} / 1$ sucrose, $0.01 \mathrm{mg} / \mathrm{l}$ IAA and $8 \mathrm{~g} / \mathrm{l}$ agar (Fig. 1A). The seeds were germinated in a growth chamber at $26 \pm 1^{\circ} \mathrm{C}$, illuminated with white fluorescent $32 \mathrm{~W}$ lamps (3000 lux) under 16/8 h photoperiod for 4-5 days.

Unexpanded or slightly expanded cotyledons coming from 4 or 5 days-old-seedlings were used for explants source (Figure 1B). Proximal cotyledon parts with hypocotyl segments were excised from seedlings as follows. Firstly, the hypocotyl was discarded near the cotyledons, and then the cotyledons were cut in half transversely and distal parts were removed. Greenish proximal parts with hypocotyl segments were cultured with the abaxial face in contact with the medium supplemented with different concentrations and combinations of BAP and TDZ (Table 1). The $\mathrm{pH}$ of the media was also adjusted to 5.8 for all culture processes. The cultures were maintained at $26 \pm 1{ }^{\circ} \mathrm{C}$, illuminated with white fluorescent $32 \mathrm{~W}$ lamps (5000 lux) under $16 / 8 \mathrm{~h}$ (day/night) photoperiod for 4 or 5 weeks. Four explants for each magenta box and six magenta boxes for each replicate were cultured for each medium and line. 

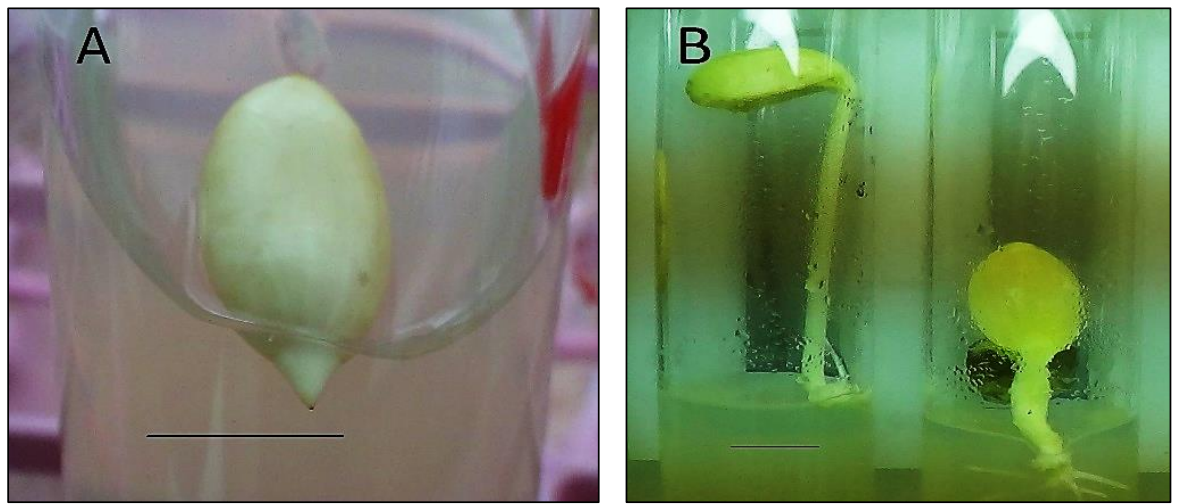

Figure 1. (A) A peeled seed in germination medium $(B)$ Germinated seeds at explant stage $($ Bars $=1 \mathrm{~cm})$.

Table 1. Media compositions

\begin{tabular}{|cccc|}
\hline & \multicolumn{3}{c|}{ PGRs } \\
\cline { 2 - 4 } Medium & BAP (mg/l) & TDZ (mg/l) & IAA (mg/l) \\
\hline M0 & - & - & - \\
M1 & 0.5 & - & - \\
M2 & 0.5 & 0.25 & - \\
M3 & 0.5 & 0.5 & - \\
M4 & 0.5 & 1.0 & - \\
M5 & 1.0 & - & - \\
M6 & 1.0 & 0.25 & - \\
M7 & 1.0 & 0.5 & - \\
M8 & 1.0 & 1.0 & - \\
R & - & - & 0.01 \\
\hline
\end{tabular}

\section{Regeneration and Acclimatization}

After 3 or 4 weeks of culture, the plantlets reached to $1.5-2.0 \mathrm{~cm}$ length on the proximal end of the cotyledon were rescued initially. The plantlets without any callus were cultured in both magenta boxes and culture tubes containing basal MS medium supplemented with $0.01 \mathrm{mg} / \mathrm{l}$ IAA and $30 \mathrm{~g} / \mathrm{l}$ sucrose for root and shoot elongation. Elongated and rooted healthy plants were individually propagated via micro-cuttings in " $R$ " medium for further growth. The regenerated plants were acclimatized as described by KURTAR and BALKAYA [16].

\section{Ploidy Determination}

The ploidy status of all regenerated plants (diploid and tetraploid) was determined via chromosome counting in root tips as described by KURTAR et al [17].

\section{Data Collection and Statistical Analysis}

A factorial experiment based on Completely Randomised Design with four replications was used in this study. The data was subjected to analysis of variance
(ANOVA) by SPSS and mean values were separated based on Duncan's multiple range test (DMRT).

\section{Results}

\section{Effect of Media on Differentiation}

At the first week, cotyledon explants enlarged and differentiated, and whitish-firmly primordial formations of embryos occurred at the end of the proximal parts (Fig. 2A). Nevertheless, some explants enlarged and differentiated, the others remained greenish and only enlarged till the end of the culture, as observed in control batch. Anomalous callus formation was only obtained from these explants along with four weeks. As presented in Table 2 and 3 , medium composition and genotype were effective on differentiation, significantly.

However, all media promoted the induction of whitish-firmly primordial formations, combinations of BAP and TDZ (in particular M8 medium) produced slightly higher differentiation percentages. On the other hand, individual supplementation of BAP and TDZ represented similar results, generally. The response in terms of differentiated explants (DE) was ranged from $74.1 \%$ (line 55 ÇA0 6 by M1 medium) to $89.3 \%$ (line $55 \mathrm{SI} 21$ by 
M8 medium) in winter squash and from $70.4 \%$ (line 14BO01 by M2 medium) to $83.2 \%$ (line G9 by M8 medium) in pumpkin. The average DE was also observed from $67.4 \%$ (line 55ÇA06) to $75.2 \%$ (line 57Sİ21) in winter squash, and it was $63.4 \%$ (line 14BO01) and $69.4 \%$ (line G9) in pumpkin. In respect to species, winter squashes showed higher differentiation response, and the mean DE was determined by $71.8 \%$ in winter squash and $66.4 \%$ in pumpkin.

Table 2. The effects of media on differentiated explants (\%), explants with the shoot (\%) and number of shoot (shoot/explant) in winter squash

\begin{tabular}{|c|c|c|c|c|}
\hline Lines & Media & DE (\%) & ES (\%) & NS (shoot/explant) \\
\hline \multirow{10}{*}{ 57Sİ21 } & M0 & $3.8( \pm 1.2)^{\mathrm{C}}$ & $0.0^{\mathrm{H}}$ & $0.0^{\mathrm{E}}$ \\
\hline & M1 & $79.2( \pm 6.5)^{\mathrm{AB}}$ & $37.5( \pm 3.3)^{\mathrm{D}}$ & $3.4( \pm 0.9)^{\mathrm{D}}$ \\
\hline & M2 & $80.6( \pm 9.8)^{\mathrm{AB}}$ & $40.7( \pm 3.1)^{\mathrm{D}}$ & $3.5( \pm 0.4)^{\mathrm{D}}$ \\
\hline & M3 & $81.9( \pm 5.8)^{\mathrm{AB}}$ & $48.8( \pm 2.9)^{\mathrm{C}}$ & $4.1( \pm 0.4)^{\mathrm{C}}$ \\
\hline & M4 & $82.3( \pm 7.9)^{\mathrm{AB}}$ & $44.8( \pm 2.6)^{\mathrm{CD}}$ & $4.9( \pm 0.7)^{C}$ \\
\hline & M5 & $85.4( \pm 9.5)^{\mathrm{A}}$ & $54.9( \pm 5.5)^{\mathrm{BC}}$ & $6.8( \pm 1.6)^{\mathrm{AB}}$ \\
\hline & M6 & $84.8( \pm 4.5)^{\mathrm{A}}$ & $61.2( \pm 4.7)^{\mathrm{B}}$ & $6.3( \pm 0.9)^{\mathrm{B}}$ \\
\hline & M7 & $87.4( \pm 3.3)^{\mathrm{A}}$ & $74.5( \pm 4.2)^{\mathrm{A}}$ & $7.4( \pm 1.4)^{\mathrm{A}}$ \\
\hline & M8 & $89.3( \pm 7.4)^{\mathrm{A}}$ & $69.7( \pm 6.9)^{\mathrm{A}}$ & $7.8( \pm 1.2)^{\mathrm{A}}$ \\
\hline & Average & $75.6^{\mathrm{A}}$ & $50.3^{\mathrm{A}}$ & $4.91^{\mathrm{A}}$ \\
\hline \multirow{10}{*}{ 55BA03 } & M0 & $0.7( \pm 0.2)^{\mathrm{C}}$ & $0.0^{\mathrm{H}}$ & $0.0^{\mathrm{E}}$ \\
\hline & M1 & $75.8( \pm 7.9)^{\mathrm{B}}$ & $30.8( \pm 3.8)^{\mathrm{E}}$ & $2.6( \pm 0.4)^{\mathrm{DE}}$ \\
\hline & M2 & $76.1( \pm 5.4)^{\mathrm{B}}$ & $34.2( \pm 4.3)^{\mathrm{DE}}$ & $2.8( \pm 0.3)^{\mathrm{DE}}$ \\
\hline & M3 & $74.3( \pm 6.1)^{\mathrm{B}}$ & $41.4( \pm 6.1)^{\mathrm{D}}$ & $3.6( \pm 0.9)^{\mathrm{D}}$ \\
\hline & M4 & $78.5( \pm 5.7)^{\mathrm{B}}$ & $39.9( \pm 4.3)^{\mathrm{D}}$ & $3.7( \pm 0.7)^{\mathrm{D}}$ \\
\hline & M5 & $80.6( \pm 5.4)^{\mathrm{AB}}$ & $47.1( \pm 6.2)^{\mathrm{C}}$ & $5.4( \pm 1.3)^{\mathrm{B}}$ \\
\hline & M6 & $82.4( \pm 4.7)^{\mathrm{AB}}$ & $51.8( \pm 4.7)^{\mathrm{C}}$ & $5.5( \pm 0.3)^{\mathrm{B}}$ \\
\hline & M7 & $80.9( \pm 6.3)^{\mathrm{AB}}$ & $54.4( \pm 5.6)^{\mathrm{BC}}$ & $6.1( \pm 1.1)^{\mathrm{B}}$ \\
\hline & M8 & $81.3( \pm 8.9)^{\mathrm{AB}}$ & $55.2( \pm 4.5)^{\mathrm{BC}}$ & $6.4( \pm 0.6)^{\mathrm{AB}}$ \\
\hline & Average & $71.7^{\mathrm{A}}$ & $41.7^{\mathrm{B}}$ & $4.01^{\mathrm{B}}$ \\
\hline \multirow{10}{*}{ 55ÇA06 } & M0 & $0.0^{\mathrm{C}}$ & $0.0^{\mathrm{H}}$ & $0.0^{\mathrm{E}}$ \\
\hline & M1 & $74.1( \pm 9.1)^{\mathrm{B}}$ & $31.4( \pm 3.3)^{\mathrm{DE}}$ & $3.0( \pm 0.7)^{\mathrm{D}}$ \\
\hline & M2 & $78.9( \pm 7.2)^{\mathrm{B}}$ & $33.8( \pm 3.7)^{\mathrm{DE}}$ & $2.9( \pm 0.2)^{\mathrm{D}}$ \\
\hline & M3 & $77.2( \pm 4.8)^{\mathrm{B}}$ & $38.3( \pm 4.9)^{\mathrm{D}}$ & $3.3( \pm 1.1)^{\mathrm{D}}$ \\
\hline & M4 & $75.4( \pm 6.2)^{\mathrm{B}}$ & $36.1( \pm 5.4)^{\mathrm{D}}$ & $3.6( \pm 0.6)^{\mathrm{D}}$ \\
\hline & M5 & $82.9( \pm 5.7)^{\mathrm{AB}}$ & $42.4( \pm 3.3)^{\mathrm{CD}}$ & $5.9( \pm 0.8)^{\mathrm{B}}$ \\
\hline & M6 & $80.7( \pm 8.9)^{\mathrm{AB}}$ & $44.1( \pm 4.1)^{\mathrm{CD}}$ & $5.7( \pm 1.5)^{\mathrm{B}}$ \\
\hline & M7 & $85.5( \pm 5.7)^{\mathrm{A}}$ & $47.9( \pm 5.1)^{\mathrm{C}}$ & $6.3( \pm 1.2)^{\mathrm{B}}$ \\
\hline & M8 & $84.3( \pm 6.1)^{\mathrm{A}}$ & $48.6( \pm 4.4)^{\mathrm{C}}$ & $6.4( \pm 1.4)^{\mathrm{AB}}$ \\
\hline & Average & $67.4^{\mathrm{B}}$ & $38.1^{\mathrm{BC}}$ & $4.12^{\mathrm{B}}$ \\
\hline \multirow{11}{*}{ 55ÇA15 } & M0 & $1.2( \pm 0.2)^{\mathrm{C}}$ & $0.0^{\mathrm{H}}$ & $0.0^{\mathrm{E}}$ \\
\hline & M1 & $76.3( \pm 7.3)^{\mathrm{B}}$ & $37.5( \pm 4.8)^{\mathrm{D}}$ & $3.4( \pm 1.0)^{\mathrm{D}}$ \\
\hline & M2 & $77.6( \pm 6.8)^{\mathrm{B}}$ & $41.2( \pm 4.2)^{\mathrm{D}}$ & $3.6( \pm 1.2)^{\mathrm{D}}$ \\
\hline & M3 & $77.8( \pm 5.7)^{\mathrm{B}}$ & $46.4( \pm 3.9)^{\mathrm{C}}$ & $4.2( \pm 1.4)^{\mathrm{C}}$ \\
\hline & M4 & $75.7( \pm 8.6)^{\mathrm{B}}$ & $42.8( \pm 5.3)^{\mathrm{CD}}$ & $5.0( \pm 0.9)^{\mathrm{C}}$ \\
\hline & M5 & $81.9( \pm 5.9)^{\mathrm{AB}}$ & $49.6( \pm 4.7)^{\mathrm{C}}$ & $6.4( \pm 1.4)^{\mathrm{AB}}$ \\
\hline & M6 & $83.3( \pm 4.6)^{\mathrm{AB}}$ & $51.8( \pm 6.4)^{\mathrm{C}}$ & $6.1( \pm 1.2)^{\mathrm{B}}$ \\
\hline & M7 & $81.0( \pm 8.7)^{\mathrm{AB}}$ & $56.5( \pm 4.4)^{\mathrm{B}}$ & $7.1( \pm 0.9)^{\mathrm{A}}$ \\
\hline & M8 & $82.4( \pm 5.5)^{\mathrm{AB}}$ & $58.7( \pm 3.8)^{\mathrm{B}}$ & $7.3( \pm 1.3)^{\mathrm{A}}$ \\
\hline & Average & $72.4^{\mathrm{A}}$ & $44.9^{\mathrm{A}}$ & $4.79^{\mathrm{A}}$ \\
\hline & Mean & 71.8 & 43.7 & 4.48 \\
\hline
\end{tabular}

Each value followed by different letters indicates a significant difference $(\mathrm{P}<0.05)$ to DMRT. Values represent the means of one hundred and twenty explants for each treatment and genotype (twenty-four in four replicates) $( \pm$ SE). M0: Control; DE: Differentiated explant; ES: Explant with shoot; NS: Number of shoot

$\mathrm{SD}_{(0.05)}$ for $\mathrm{DE}=8.67 ; \mathrm{SD}_{(0.05)}$ for $\mathrm{ES}=10.82 ; \mathrm{SD}_{(0.05)}$ for $\mathrm{NS}=1.34$ 
Table 3. The effects of media on differentiated explants (\%), explants with the shoot (\%) and number of shoot (shoot/explant) in pumpkin

\begin{tabular}{|c|c|c|c|c|}
\hline Lines & Media & DE (\%) & ES (\%) & NS (shoot/explant) \\
\hline \multirow{10}{*}{ 14BO01 } & M0 & $0.0^{\mathrm{E}}$ & $0.0^{\mathrm{F}}$ & $0.0^{\mathrm{E}}$ \\
\hline & M1 & $73.1( \pm 6.1)^{\mathrm{BC}}$ & $29.7( \pm 1.3)^{\mathrm{E}}$ & $2.1( \pm 0.3)^{\mathrm{DE}}$ \\
\hline & M2 & $70.4( \pm 5.6)^{\mathrm{C}}$ & $34.6( \pm 4.4)^{\mathrm{DE}}$ & $2.7( \pm 0.3)^{\mathrm{DE}}$ \\
\hline & M3 & $72.3( \pm 8.7)^{\mathrm{BC}}$ & $40.3( \pm 2.9)^{\mathrm{D}}$ & $3.4( \pm 1.1)^{\mathrm{CD}}$ \\
\hline & M4 & $71.6( \pm 7.9)^{\mathrm{BC}}$ & $39.4( \pm 4.7)^{\mathrm{D}}$ & $3.3( \pm 0.7)^{\mathrm{CD}}$ \\
\hline & M5 & $76.2( \pm 4.2)^{\mathrm{B}}$ & $44.6( \pm 3.8)^{\mathrm{CD}}$ & $5.1( \pm 1.5)^{\mathrm{BC}}$ \\
\hline & M6 & $75.7( \pm 5.3)^{\mathrm{B}}$ & $43.9( \pm 2.2)^{\mathrm{CD}}$ & $5.5( \pm 1.6)^{\mathrm{BC}}$ \\
\hline & M7 & $74.2( \pm 6.1)^{\mathrm{B}}$ & $47.8( \pm 3.4)^{\mathrm{C}}$ & $5.9( \pm 0.5)^{\mathrm{B}}$ \\
\hline & M8 & $78.8( \pm 5.7)^{\mathrm{B}}$ & $52.1( \pm 5.5)^{\mathrm{D}}$ & $6.2( \pm 1.2)^{\mathrm{B}}$ \\
\hline & Average & $63.4^{\mathrm{B}}$ & $39.1^{\mathrm{AB}}$ & $3.80^{\mathrm{AB}}$ \\
\hline \multirow{11}{*}{ G9 } & M0 & $0.6( \pm 0.1)^{\mathrm{D}}$ & $0.0^{\mathrm{F}}$ & $0.0^{\mathrm{E}}$ \\
\hline & M1 & $77.4( \pm 7.4)^{\mathrm{B}}$ & $33.9( \pm 4.9)^{\mathrm{DE}}$ & $2.9( \pm 0.1)^{\mathrm{DE}}$ \\
\hline & M2 & $78.2( \pm 6.8)^{\mathrm{B}}$ & $37.5( \pm 3.1)^{\mathrm{D}}$ & $3.1( \pm 1.5)^{\mathrm{D}}$ \\
\hline & M3 & $79.5( \pm 9.5)^{\mathrm{B}}$ & $44.4( \pm 3.3)^{\mathrm{CD}}$ & $3.9( \pm 1.1)^{\mathrm{D}}$ \\
\hline & M4 & $77.1( \pm 5.5)^{\mathrm{B}}$ & $43.1( \pm 4.0)^{\mathrm{CD}}$ & $3.7( \pm 0.8)^{\mathrm{CD}}$ \\
\hline & M5 & $82.0( \pm 4.7)^{\mathrm{AB}}$ & $46.6( \pm 2.9)^{\mathrm{CD}}$ & $5.4( \pm 0.7)^{\mathrm{BC}}$ \\
\hline & M6 & $80.3( \pm 8.0)^{\mathrm{AB}}$ & $47.8( \pm 3.4)^{\mathrm{C}}$ & $5.7( \pm 0.8)^{\mathrm{B}}$ \\
\hline & M7 & $81.7( \pm 5.9)^{\mathrm{AB}}$ & $51.5( \pm 4.5)^{\mathrm{C}}$ & $6.8( \pm 1.1)^{\mathrm{AB}}$ \\
\hline & M8 & $83.2( \pm 6.5)^{\mathrm{AB}}$ & $58.7\left( \pm 3.9^{\mathrm{B}}\right.$ & $6.7( \pm 1.9) \mathrm{AB}$ \\
\hline & Average & $69.3^{\mathrm{A}}$ & $42.6^{\mathrm{A}}$ & $4.25^{\mathrm{A}}$ \\
\hline & Mean & 66.4 & 40.9 & 4.03 \\
\hline
\end{tabular}

Each value followed by different letters indicates a significant difference $(\mathrm{P}<0.05)$ to DMRT. Values represent the means of one hundred and twenty explants for each treatment and genotype (twenty-four in four replicates) $( \pm$ SE). M0: Control; DE: Differentiated explant; ES: Explant with shoot; NS: Number of shoots $\mathrm{SD}_{(0.05)}$ for $\mathrm{DE}=8.67 ; \mathrm{SD}_{(0.05)}$ for $\mathrm{ES}=10.82 ; \mathrm{SD}_{(0.05)}$ for $\mathrm{NS}=1.34$

\section{Effect of Media on Regeneration}

Multiple plantlets were obtained from primordial formations within the second week of culture (Fig. 2B). Some explants rarely produced radicle with the shoot (Fig. 2C). Callus formation was not observed along with two weeks. The percentage of explants with the shoot (ES) and number of shoot per explant (NS) were served as an indicator for the impact of regeneration capacity. It has been well documented that frequency of ES and NS was also influenced by genotype and medium, statistically. All combinations of BAP and TDZ produced the shoot regeneration in all lines.

However, the hormone-free medium did not respond on shoot regeneration for all lines. It was noted that significant correlation was observed between BAP and TDZ. Nevertheless, their combinations created a synergistic effect and introduced significant increase on shoot formation in both species and lines; ES and NS generally resulted in decrease by individual supplementation of BAP and TDZ, statistically. In our findings, among the various concentrations of BAP and TDZ, $1 \mathrm{mg} / \mathrm{l} \mathrm{BAP}+0.5 \mathrm{mg} / \mathrm{l}$ TDZ (M7 medium) and $1 \mathrm{mg} / \mathrm{l} \mathrm{BAP}+1 \mathrm{mg} / \mathrm{l} \mathrm{TDZ}$ (M8 medium) were the most efficient combinations in promoting both ES and NS obtained from each of the explants in winter squash and pumpkin. However, ES and NS response were below the average when explants were cultured MS medium supplemented with individual treatments of BAP and TDZ.

\section{Effect of Lines on Regeneration}

The ES values ranged from $30.8 \%$ (line 55BA03 by M1 medium) to $74.5 \%$ (line $55 \mathrm{SI} 21$ by M7 medium) in winter squash and from $29.7 \%$ (line $14 \mathrm{BO} 01$ by M1 medium) to $58.7 \%$ (line G9 by M8 medium) in pumpkin. The average ES was observed from $38.1 \%$ (line 55ÇA06) to $50.3 \%$ (line $57 \mathrm{SI} 21$ ) in winter squash, and it was $38.1 \%$ (line 14BO01) and 44.9\% (line G9) in pumpkin. In respect to species, winter squash and pumpkin lines showed similar differentiation response, and the mean ES was determined by $44.9 \%$ in winter squashes, and $42.6 \%$ in pumpkins. Likewise, the strong genotypic differences were determined, and species and lines represented a wide range of NS performance. In relation to regeneration media, NS was counted by 2.1 in line $14 \mathrm{BO} 01$ with M1 medium, and by 7.8 in line 57Sİ 21 with M8 medium, averagely. The highest NS was achieved by 7.8 in line 57 Si 21 (M8 medium) in winter squash, and followed by 6.8 in line G9 (M7 medium) in pumpkin whereas, in hormone free control MS medium, explants did not produce any shoot regeneration. The average NS was ranged from 4.01 (line 55BA03) to 4.91 (line 57Sİ21) in winter squash, and it was 3.80 (line 14BO01) and 4.25 (line G9) in pumpkin. Winter squash showed higher differentiation response and the mean NS was determined with 4.48 in winter squashes, and 4.03 in pumpkins. 

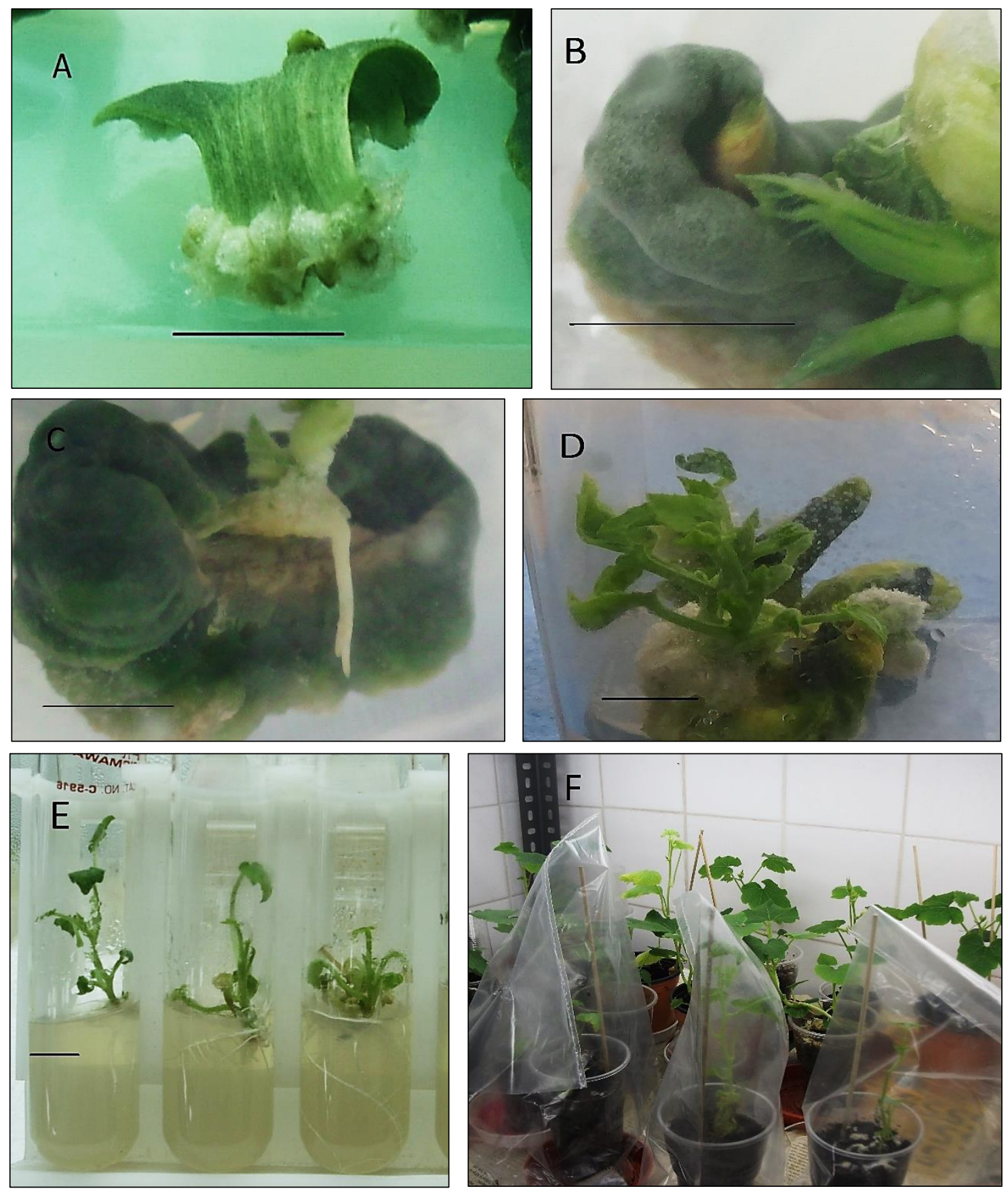

Figure 2. (A) Cotyledon explants with whitish and firmly primordial formations. (B) Shoot proliferation from the primordial structure. (C) Radicle and shoot proliferation in a cotyledon explant. (D) Younger plantlets with leaflets on explants. (E) Plantlets in rooting medium. (F) Acclimatised plantlets in climate room. (Bars of A, B and $\mathrm{C}=0.5 \mathrm{~cm}$; Bars of $\mathrm{D}$ and $\mathrm{E}=1 \mathrm{~cm})$.

In respect to individual supplementation of BAP and TDZ, TDZ was found to be prominent cytokine for induction of ES and NS. As seen in Table 2 and 3, the addition of TDZ in culture conditions (M3 and M4 media) resulted in higher ES and NS values than BAP (M3 and M4 media) in winter squash and pumpkin lines. Despite many regenerants well developed and rooted in MS medium, a few plants did not survive and aborted due to hyperhydricity and abnormal shoot growth in culture conditions (data not shown). Besides, somaclonal variation was not detected under in vitro conditions and the features of plants were observed in normal morphology.

\section{Elongation, Acclimatization and Ploidy Determination}

After 3 weeks of culture, younger plantlets having two or three leaflets with hypocotyl segment were initially excised from proximal parts and were cultured in MS medium supplemented with $0.01 \mathrm{mg} / 1 \mathrm{IAA}$ for the shoot and root elongation (Fig. 2D and 2E), individually. At the end of the regeneration process, 122 plants (91 of winter 
squash and 31 of pumpkin) were elongated and rooted. Well-generated complete plants were propagated by microcuttings. Micropropagated plants were acclimatized with $84 \%$ survival rate as described by Kurtar and Balkaya (2010) (Fig. 2F). Ploidy analyses revealed that 118 plants were diploid and the others were tetraploid. Tetraploid plants were observed in line 57Sİ21 (3 plants) and line 55ÇA15 (1 plant) by M8 medium. Tetraploid plantlets have larger, darker and thicker leafs, higher stomata dimensions but lower stomata density than diploid regenerants.

\section{Discussion}

Explants differentiation and shoot regeneration were achieved with alone or in combination of BAP and TDZ using proximal cotyledon parts with hypocotyl segments of winter squash and pumpkin seedlings. However, the best results were obtained from combinations of BAP and TDZ, and individual supplementation of BAP and TDZ showed a decrease in shoot regeneration. The combinations of BAP end TDZ led to synergistic effect and promoted the shoot induction during the regeneration phase, significantly.

BAP and TDZ have been widely used to enhance the in vitro shoot induction and shoot regeneration in Cucurbits. The optimum results in terms of PGRs were obtained by MS medium supplementation of BA (STIPP et al [12]), TDZ (KURTAR and BALKAYA [16]), BA + TDZ (MOOKHAN [13]) in Cucurbita pepo, BA + IAA (GROZEVA and VELKOV [5]) in Cucumis sativus, BA (CURUK et al [8]; NTUI et al [19]) and Kin + IAA (TEKDAL and CETINER [10]) in Cucumis melo and BA + IAA (MENDI et al [20]) in Cucumis melo var. flexuosus. Furthermore, BA promoted the shoot induction in Cucurbita maxima (LEE et al [2]), Cucurbita moschata (ZHANG et al [3]) and Citrullus lanatus (WANG et al [6]; ZHANG et al [1]). The results of these reports clearly indicated that BA is exclusively requirement for promoting the shoot regeneration in Cucurbits. Nevertheless, the importance of TDZ for shoot regeneration was also reported in Cucurbita pepo (PAL et al [18]), and TDZ was found to be more effective than BA. Accordingly, we combined BAP and TDZ to promote direct shoot regeneration of Cucurbita maxima and Cucurbita moschata for the first time. The findings of our research indicated that the combinations of BAP and TDZ were more effective than their use alone for induction of shoot regeneration. Likewise, the shoot regeneration was stimulated with the combination of BAP and TDZ in Cucurbita pepo (MOOKHAN [13]).

On the other hand, the explant types and seedling age are important factors in the regeneration process. In Cucurbita pepo L., cotyledon explants (MOOKHAN [13]) and hypocotyl segments (STIPP et al [12]; PAL et al [18]) were found to be favorable in shoot regeneration. Nevertheless, proximal cotyledon parts with hypocotyl segments were determined the prominent explants in squash, winter squash and pumpkin due to their high organogenic competence (LEE et al [2]; ZHANG et al [3]). The cotyledon explants from 4-day-old seedling were more effective on shoot induction in winter squash (LEE et al [2]), in contrast, 7-day-old seedlings produced favorable results in pumpkin (ZHANG et al [3]). In this way, to enhance the shoot regeneration, proximal cotyledon parts with hypocotyl segments collected from 4 or 5-day-old in vitro germinated seedlings of winter squash and pumpkin lines were cultured in our study.

Genotype specificity was observed, and the favorable results were obtained from lines $57 \mathrm{SI} 21$ (4.91 shoot per explant) and 55ÇA15 (4.70) in winter squash and line G9 (4.25) in pumpkin. Data presented in this research confirmed the relationship between shoot regeneration and genotype that has been previously reported for Cucurbita pepo (PAL et al [18]) and in Cucurbita maxima (LEE et al [2]). Shoot regeneration was obtained from all winter squash and pumpkin lines and average values varied in the range of $2.1-7.8$ shoot per explant. On the other hand, the frequency of shoot per explants was determined by 4.4 in winter squash (LEE et al [2]), $3.3-4.0$ in pumpkin (ZHANG et al [3]), $1.1-6.9$ (PAL et al [18]) and 3.6 (STIPP et al [12]) in squash. Interestingly, MOOKHAN [13] reported 14.2 and 12.0 shoot per explants in Cucurbita реро, respectively. On the other hand, hyperhydricity and abnormal shoot growth were observed in regenerated plantlets. All plants were morphologically indistinguishable and no variation was observed in regenerants. Because we studied direct regeneration protocol, moreover the plants were at early stages of growing. In view of our findings, it is clearly reflected that direct regeneration protocol produced more stable regenerants in winter squash and pumpkin as reported in cumin (EBRAHIMIE et al [21]), coffea (KUMAR et al [22]) and cotton (PATHI and TUTEJA [23]).

The results of ploidy analyses supported the effectiveness of our protocol due to the higher frequency (97\%) of diploid regenerants. However, all tetraploid regenerants were observed in supplementation of $1 \mathrm{mg} / \mathrm{l} \mathrm{BAP}+1 \mathrm{mg} / \mathrm{l}$ TDZ (M8 medium). In accordance our findings, only a single tetraploid plant was determined by high cytokine concentration in winter squash (LEE et al [2]). Tetraploidy frequency varied from $13.5 \%$ to $6.9 \%$ in Cucumis metuliferus (ADELBERG [24]), and polyploid (tetraploid and mixoploid) regenerants were determined in Cucumis melo L. inodorus (REN et al [25]). The majority of the regenerants were diploids (from $47 \%$ to $70 \%$ ) and tetraploids (from $30 \%$ to $47 \%$ ) in Arabidopsis thaliana (ORZECHOWSKA et al [26]).

\section{Conclusion}

Cotyledon explants of winter squash and pumpkin lines produced remarkable shoot regeneration when cultured on solid MS medium supplemented with $1 \mathrm{mg} / \mathrm{l}$ $\mathrm{BAP}+0.5 \mathrm{mg} / \mathrm{l} \mathrm{TDZ}$ and $1 \mathrm{mg} / \mathrm{l} \mathrm{BAP}+1 \mathrm{mg} / \mathrm{l} \mathrm{TDZ}$, compared to BAP and TDZ alone. Shoots were successfully elongated and rooted in MS medium with the addition of $0.01 \mathrm{mg} / \mathrm{l}$ IAA. To establish more productive regeneration protocol for a large-scale in mentioned species, it is strongly suggested that the future shoot regeneration experiments should be based on the different concentrations of combinations of BAP + TDZ due to their synergistic effects. 


\section{Acknowledgments}

We gratefully acknowledge the support of the Ondokuz Mayis University (Project No: PYO.BMY. 1901.13.001), Samsun, Turkey.

\section{References}

1. ZHANG, V., REN, Y., SUN, H., GUO, S. et al., A highdensity genetic map for anchoring genome sequences and identifying QTLs associated with dwarf vine in pumpkin (Cucurbita maxima Duch.). BMC Genomics, 2015; 16: 1101.

2. LEE, Y.K., CHUNG, W.I., EZURA, H., Efficient plant regeneration via organogenesis in winter squash (Cucurbita maxima Duch.). Plant Sci., 2003; 164: 413-418.

3. ZHANG, Y., ZHOU, J., WU, T., CAO, J., Shoot regeneration and the relationship between organogenic capacity and endogenous hormonal contents in pumpkin. Plant Cell Tiss. Organ Cult., 2008; 93: 323-331.

4. VASEDUVAN, A., SELVARAJ, N., GANAPATHI, A., CHOI, C.W., Agrobacterium-mediated genetic transformation in cucumber (Cucumis sativus L.). Am. J. Biotech. Biochem., 2007; 3: 24-32.

5. GROZEVA, S., VELKOV, N., In vitro plant regeneration of two cucumbers (Cucumis sativus L.) genotypes: effects of explant types and culture medium. Genetika, 2014; 46: 485-493.

6. WANG, X., SHANG, L., LUAN, F., A highly efficient regeneration system for watermelon (Citrullus lanatus Thunb.). Pak. J. Bot., 2013; 45: 145-150.

7. ZHANG, L., LAI, J., TANG, Y., MA, J., LI, H., Improved induction of somatic embryo in watermelon (Citrullus lanatus (Thunb.) Matsum. et Nakai). Journal of Agric. Sci., 2014; 6: 81-89.

8. CURUK, S., ELMAN, C., SCHLARMAN, E., SAGEE, et al., A novel pathway for rapid shoot regeneration from the proximal zone of the hypocotyl of melon (Cucumis melo L.). In Vitro Cell. \& Develop. Bio. -Plant, 2002; 38: 260-267.

9. RHIMI, A., FADHEL, B.N., BOUSSAID, M., Plant regeneration via somatic embryogenesis from in vitro tissue culture in two Tunisian Cucumis melo cultivars Maazoun and Beji. Plant Cell Tiss. Org. Cult., 2006; 84: 239-243.

10. TEKDAL, D., CETINER, S., The effects of different combinations and varying concentrations of growth regulators on the regeneration of selected Turkish cultivars of melon. Current Progress in Biol. Res., Silva-Opps, Marina (ed.), Acadia, Canada: InTech, 2013; 257-275.

11. ANANTHAKRISHNAN, G., XIA, X., AMUTHA, S., SINGER, et al., Ultrasonic treatment stimulates multiple shoot regeneration and explant enlargement in recalcitrant squash cotyledon explants in vitro. Plant Cell Rep., 2007; 26: 267-276

12. STIPP, L.C.L., ACBA, M.H., MENDES, B.M.J., In vitro organogenesis of zucchini squash cv. Caserta. Hort. Brasil., 2012; 30: 274-278.

13. MOOKHAN, M., Direct organogenesis from cotyledonary node explants of Cucurbita pepo (L.) - An important zucchini type vegetable crop. Amer. J. of Plant Sci., 2015; 6: 157-162.

14. MENDI, Y.Y., UNEK, C., ELDOGAN, S., AKA KACAR, Y., et al., The effects of different hormones on regeneration of gazania (Gazania rigens). Romanian Biotec. Let., 2009; 14: 4728-4732.

15. PETROVA, M., ZAYOVA, E., YANKOVA, E., BALDZHIEV, G., Plant regeneration from callus culture of Arnica montana. Romanian Biotec. Let., 2011; 16(1): 92-97.

16. KURTAR, E.S., BALKAYA, A., Production of in vitro haploid plants from in situ induced haploid embryos in winter squash (Cucurbita maxima Duchesne ex Lam.) via irradiated pollen. Plant Cell Tiss. Organ Cult., 2010; 102: 267-277.

17. KURTAR, E.S., BALKAYA, A., KANDEMIR, D., Evaluation of haploidization efficiency in winter squash (Cucurbita maxima Duch.) and pumpkin (Cucurbita moschata Duch.) through anther culture. Plant Cell Tiss. Organ Cult., 2016; DOI: 10.1007/s11240-016-1074-6.

18. PAL, S.P., ALAM, I., ANISUZZAMAN, M., SARKER, K.K., et al., Indirect organogenesis in summer squash (Cucurbita pepo L.). Turk. J. Agric. Forest., 2007; 31: 63-70.

19. NTUI, V.O., THIRUKKUMARAN, G., LIOKA, S., MII, M., Efficient plant regeneration via organogenesis in 'Egusi' melon (Colocynthis citrullus). Sci. Hort., 2009; 119: 397-402.

20. MENDI, Y.Y., ELDOĞAN, S., GUTAKEV, R., IPEK, M, et al., Regeneration and histological analysis of snake melon (Cucumis melo var. flexuosus (L.) Naudin) by direct organogenesis. Turk. J. Agric. For., 2010; 34: 309-317.

21. EBRAHIMIE, E., HOSSEINZADEH, A., NAGAVI, M.R., GHANNADHA, M., et al., Combined direct regeneration protocols in tissue culture of different cumin genotypes based on pre-existing meristems. Pakistan J. of Biol. Sci., 2007; 10: 1360-1370.

22. KUMAR, V., SATYANARAYANA, K.V., ITTY, S.S., INDU, E.P., et al., Stable transformation and direct regeneration in Coffea canephora $\mathrm{P}$ ex. Fr. by Agrobacterium rhizogenes mediated transformation without hairy-root phenotype. Plant Cell Rep., 2006; 25: 214-222.

23. PATHI, K.M., TUTEJA, N., High-frequency regeneration via multiple shoot induction of an elite recalcitrant cotton (Gossypium hirsutum L. cv Narashima) by using embryo apex. Plant Signal Behav., 2013; 8(1): 22763.

24. ADELBERG, J.W., Regeneration and frequency of tetraploid variants of Cucumis metuliferus are affected by explant induction on semi-solid medium versus the liquid/ membrane system. Plant Cell Rep., 1998; 17(3): 225-229.

25. REN, Y., BANG, H., GOULD, J., RATHORE, K.S., et al., Shoot regeneration and ploidy variation in tissue culture of honeydew melon (Cucumis melo L. inodorus). In Vitro Cell. Dev. Biol., 2013; 49: 223-229.

26. ORZECHOWSKA, M., STEPIEN, K., KAMINSKA, T., SIWINSKA, D., Chromosome variations in regenerants of Arabidopsis thaliana derived from 2- and 6-week-old callus detected using flow cytometry and FISH analyses. Plant Cell Tiss. Organ Cult., 2013; 112(3): 263-273. 